\title{
Effect of some food additives on color enhancement of koi fish, Cyprinus carpio (Linnaeus, 1758)
}

\author{
Ahmad M. Azab, Hassan M.M. Khalaf-Allah and Hany Maher \\ Marine Biology branch, Zoology Department, Faculty of Science, \\ Al-Azhar University, Cairo, Egypt
}

\begin{abstract}
The present work was carried out to investigate the effect of some food additives (turnip leafs and roots, grape leafs and carrot roots) on enhancement colour of koi fish, Cyprinus carpio. Fish were divided into 8 groups in 16 glass aquaria $(100 \times 30 \times 40 \mathrm{~cm})$ with stocking density of 10 fish / aquarium ( 2 replicate aquaria were assigned for each experimental group). Fish were fed on plain food as a control $(\mathrm{C})$, plain diet $+5 \%$ turnip $\left(\mathrm{T}_{1}\right)$, plain diet $+5 \%$ grape $\left(\mathrm{T}_{2}\right)$, plain diet+ $5 \%$ carrot $\left(\mathrm{T}_{3}\right)$, plain diet $+5 \%$ grape + carrot $\left(\mathrm{T}_{4}\right)$, plain diet $+5 \%$ grape + turnip $\left(\mathrm{T}_{5}\right)$, plain diet + $5 \%$ carrot + turnip $\left(\mathrm{T}_{6}\right)$ and plain diet $+5 \%$ turnip + grape $+\operatorname{carrot}\left(\mathrm{T}_{7}\right)$ over 4 months.

Results showed that, the highest amount of the red color pixels was recorded in the treated fish group $\mathrm{T}_{7}$ (fed on the 3 mixed food additives) at 30, 60, 90 and 120 days; followed by that of $\mathrm{T}_{6}$ (carrot + turnip) at 60 and 90 days and in $\mathrm{T}_{4}$ (grape +carrot) at 90 and 120 days.

Results also revealed that, the highest amount of the yellow color pixels was recorded at 90 and 120 days in the treated fish group $\mathrm{T}_{3}$ (carrot). But, the highest amount of the yellow color pixels was recorded in $\mathrm{T}_{4}$ (grape +carrot) at 30 and 60 days; followed by that of $\mathrm{T}_{6}$ (carrot + turnip) at 60, 90 and 120 days.

Results showed that, the highest amount of total color pixels was recorded in $\mathrm{T}_{3}$ (carrot) at 60, 90 and 120 days; followed by that of $\mathrm{T}_{6}$ (carrot + turnip) and in $\mathrm{T}_{4}$ (grape +carrot) at 60, 90 and 120 days.

In conclusion the best enhancement of red color in koi fish, C. carpio was recorded in the fish fed on the diet containing 5\% of the mixture of all experimental additives (carrot roots+ grape leafs+ turnip leafs and roots). The enhancement of yellow color was recorded in fish fed on the diet containing 5\% "carrot roots" for more than 30 days. The enhancement of total color of koi fish, $C$. carpio was recorded in fish fed on the diet containing 5\% "carrot roots, or carrot roots with turnip leafs and roots".
\end{abstract}

Key words: food additives; enhancement; color; koi fish, Cyprinus carpio

\section{INTRODUCTION}

Ornamental fish keeping is one of the most popular hobbies in the world today. The growing interest in aquarium fish had resulted in a steady increase in aquarium fish trade globally. This trade has a turnover rate of 5 billion \$USD and an annual growth rate of $8 \%$ and offer a wide of scope for development. The top exporting country is Singapore followed by Hong Kong, Malaysia, Thailand, Philippines, Sri Lanka, Taiwan, Indonesia and India. The largest importer of ornamental fish is the USA followed by Europe and Japan. The emerging markets are China and South Africa. Over US \$ 500 million worth of ornamental fish are imported into the USA each year ${ }^{(1)}$. 
Ahmad M. Azab et al.

The common carp, Cyprinus carpio (Linnaeus 1758), are members of the family Cyprinidae, or minnow family. Koi fish is an ornamental variety of the common carp. The Japanese ornamental koi carp, $C$. carpio is a popular decorative fish in many countries all over the world. Koi were developed approximately two centuries ago in Japan and are characterized by a wide diversity of colors and color patterns ${ }^{[2-3]}$. The colour and scale pattern (squamation) of the species is highly variable. A variety of colours and colour patterns have since been developed; common colours include white, black, red, yellow, blue, and cream. They grow up to $100 \mathrm{~cm}$ total length with an elongate body measuring 3 to 4 times less in height than total length. In their natural habitat, koi carp live up to 15-24 years. Males are known to live longer than females ${ }^{[3]}$.

Color is one of the major factors, which determines the price of aquarium fish in the world market. Ornamental fish are acceptable to consumers if they have striking and vibrant colors. Fish skin color is mainly attributed to the presence of chromatophores that contain pigments including melanin, pteridines, purines and carotenoids. Fish are capable of producing some pigments. Since fish, like other animals are unable to synthesize carotenoids ${ }^{[4-6]}$.

However, dietary sources of pigments also play a role in determining some pigments. The carotenoid pigmentation of fish results from the pigment present in the diet. So, skin color is highly dependent on the carotenoids presents in the diets of most fish. Hence, a direct relationship between dietary carotenoids and pigmentation exists in them ${ }^{[7-8]}$.

Color enhancing diets may contain additional natural pigments to enhance colors of ornamental fish. People involved in the trade of ornamental fish are constantly exploring methods of enhancing skin coloration. Many studies have proved that, the fish can be pigmented by supplementation of plants sources ${ }^{[6,9-13]}$.

Thus, this work aimed to study the effect of some plant additives (leaf and root of turnip, leaf of grape and carrot roots) to fish diet on the color enhancement of koi fish, Cyprinus carpio (Linnaeus, 1758).

\section{MATERIAL AND METHODS}

\section{Experimental fish:}

A total of 160 specimens of Koi fish, Cyprinus carpio (Fig. 1), with a good condition were obtained from a private farm at Kafr El-Shaikh Governorate. All fish samples were pre-adults, and they greatly similar in weight $(5.07 \pm 1 \mathrm{~g})$. Fish were transported to the fish laboratory at Animal House of Zoology Department, Faculty of Science, Al-Azhar University; in large plastic bags, each containing approximately $20 \mathrm{~L}$ of water and a lot of oxygen. In the laboratory, fish were acclimatized for one week in well aerated large glass tanks $(100 \times 50 \times 50 \mathrm{~cm})$. Fish were fed daily on a commercial fish diet. All fish specimens were kept in the laboratory conditions (temperature: $20 \pm 2^{\circ} \mathrm{C}$ ); and fed on the main experimental diet for 2 months, before the beginning of the experiment.

\section{Experimental diets:}

The main experimental fish diet $30 \%$ protein was bought from fish diet factory at October City. This fish diet was sinking pellets. It used for all fish during the preparatory period (the first 2 months). Also, it used as a control diet for control fish group. Then, it used as a plain for all the treatment diets. Seven treatment diets were prepared by adding 50 grams $(5 \%)$ of testing additive to 950 grams $(95 \%)$ of basic diet. The basic diet was grinded and milled. 


\section{Effect of some food additives on color enhancement of koi fish, Cyprinus carpio (Linnaeus, 1758)}

The experimental additives are root of carrot, grape leaf and leaf and root of turnip. These additives were hot air dried in electric oven at $40-50^{\circ} \mathrm{C}$ for 3 hours; then they were grinded and milled. The ingredients of basic diet and the proper additives were weighed and mixed. Then, they were pelleted with meat mincer through a $0.8 \mathrm{~mm}$ diameter. After cold pelleting, the feeds were hot air dried in electric oven at $40^{\circ} \mathrm{C}$ for 4 hours. All prepared diets were put in air tight containers, and stored in dry-weathered place until it used in fish feeding. Feed preparation was carried out monthly to prevent long storage. The experimental eight diets were prepared as diagrammatically shown in Figure (2).

\section{Fish grouping and experiment:}

After acclimatization and preparatory periods, fish divided into 8 groups in 16 glass aquaria $(100 \times 30 \times 40 \mathrm{~cm})$ with stocking density of 10 fish / aquarium (2 replicate aquaria were assigned for each experimental group). Fish groups were fed with different fed rations (C, T1, T2, T3, T4, T5, T6 and T7) respectively. Fish were feeding by plain food as a control (C), diet contains 5\% turnip (leaf and root) (T1), diet contains 5\% grape (leaf) (T2), diet contains 5\% carrot ( root) (T3), diet contains 5\% grape( leaf) + carrot ( root) (T4), diet contains 5\% grape (leaf) + turnip (leaf and root) (T5), diet contains 5\% carrot ( root) + turnip (leaf and root) (T6) and diet contains 5\% turnip (leaf and root) + grape (leaf) + carrot ( root) (T7). Fish were fed twice daily, six days a week at a fixed feeding rate of $2 \%$ of body fish weight (dry feed/ day).

The feeding rate adjusted at monthly intervals- where 32 fish were randomly selected from all group (2 fish from each aquarium), weighted; and the average fish weight was obtained and the monthly feed intake (g feed / fish /month) was calculated for each group. Half of the water volume, for all aquaria, was replaced once every week with de-chlorinated fresh tap water after removing the wastes (diet and excreta).

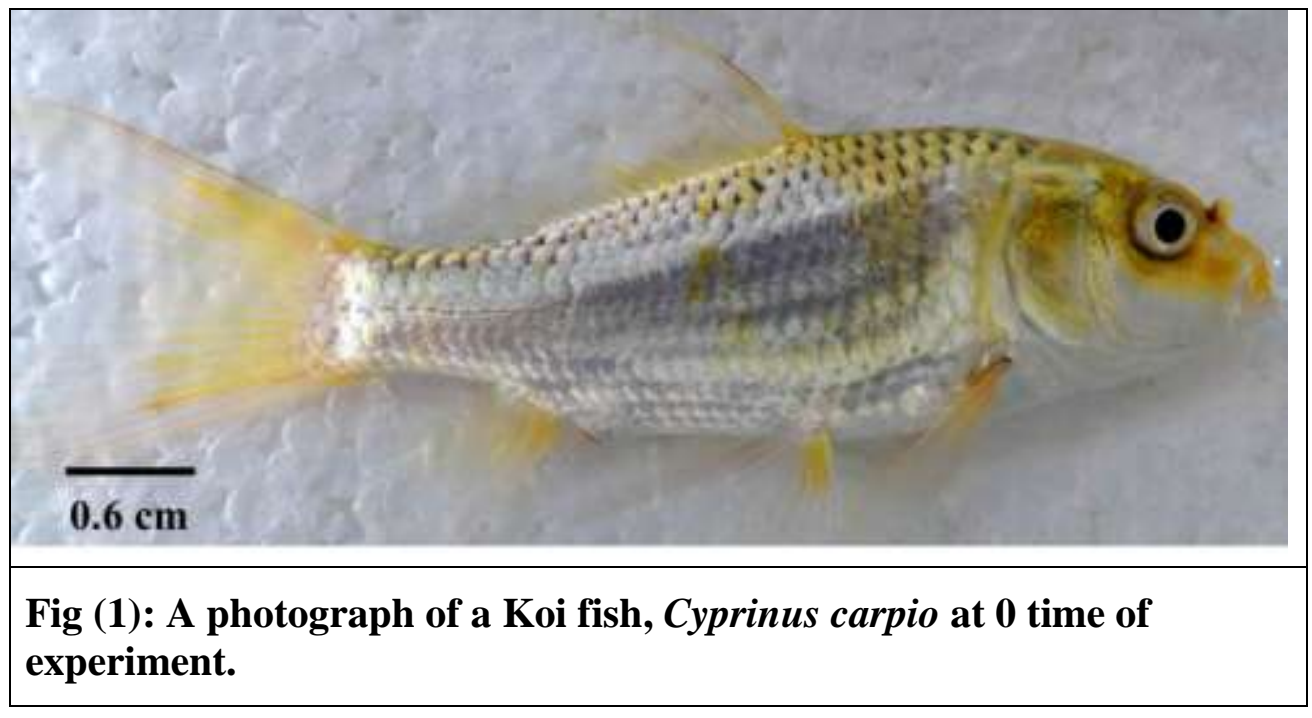




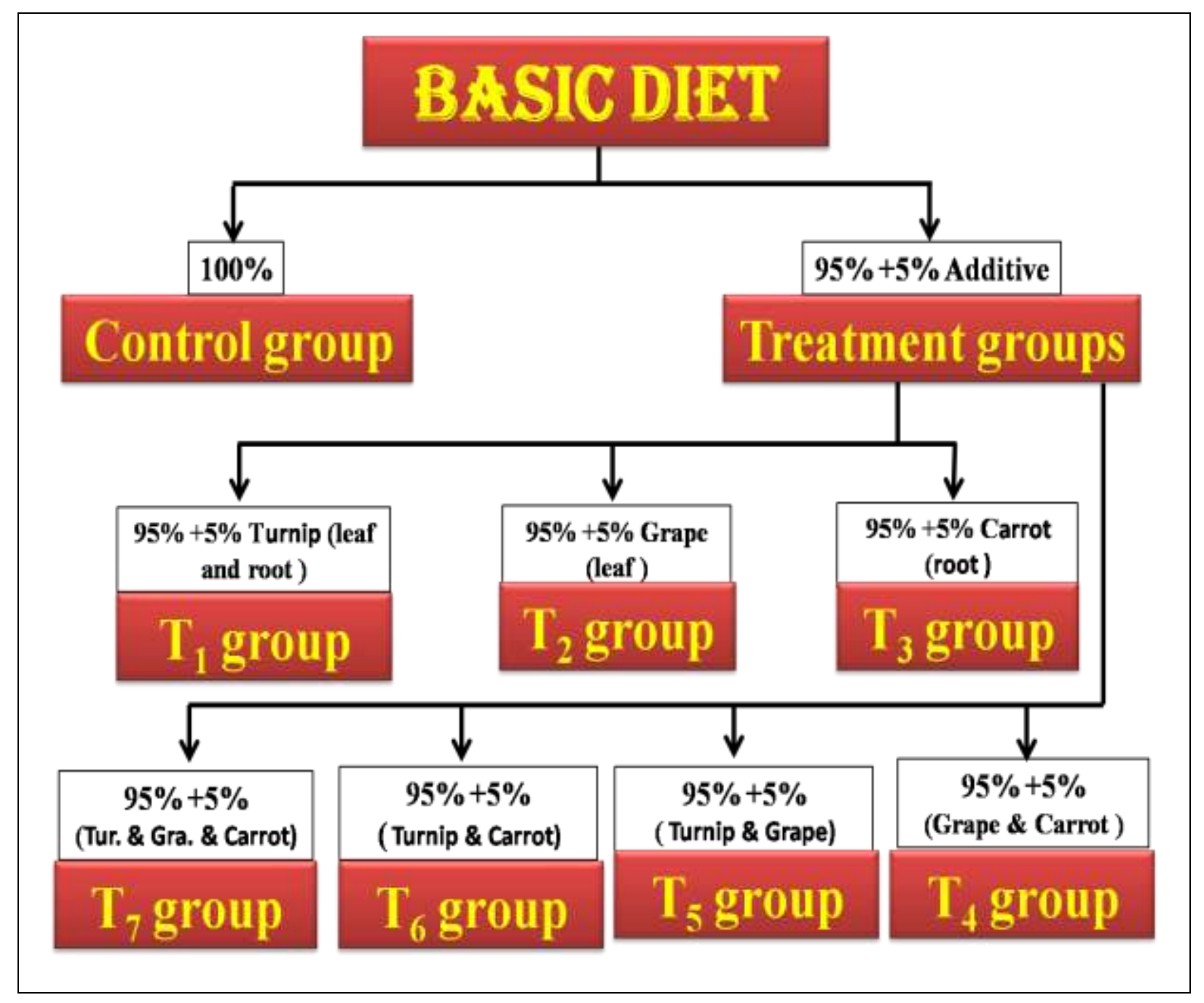

Fig. (2): A diagram showing the preparation of different experimental diets.

\section{Coloration studies:}

To evaluate the enhancement of fish color, 10 fishes from each group (control and treatment groups) were monthly photographed by a digital camera. These fish photographs were taken with similar dimensions and resolution. The digital photographs were then treated by the Adobe Photoshop 7 computerized program. These photographs were re-formatted as follows: Pixel dimensions: 400 width x 300 height pixels. Document size: 5.556 x 4.167 inches (width x height). Resolution: 72 pixels / inch.

In Adobe Photoshop program, the amount of pixels for the very important colors of koi fish (Red and Yellow) was detected and recorded.

\subsection{Amount of color pixels:}

The method of detecting the amount of red color pixels can be summarized in the following steps:

1) Press on File button in the tools bar; then press on Open in its list to select the fish picture.

2) Press on Select button in the tools bar; then press on Color Range in its list. 


\section{Effect of some food additives on color enhancement of koi fish, Cyprinus carpio (Linnaeus, 1758)}

3) In appeared window, select the Red color and press OK. The red color pixels in the picture will be flashed on.

4) Press on Image button in the tools bar; then press on Histogram in its list.

5) In the appeared window, we find the detected Pixels amount of the red color.

For detecting the amount of yellow color pixels, we repeat the steps $(2-5)$.

\section{RESULTS \\ 1. Effect of food additives on color pixels amount: \\ The effect of different feed rations (C, T1, T2, T3, T4, T5, T6 and T7) on the color pixels amount in the digital photographs of koi fish, $C$. carpio, reared for 120 days are given in Tables (1- 3), Figures (3 - 5) and Plates (I - II).}

\subsection{Red color:}

The amount of red color pixels in the digital photographs of koi fish, C. carpio, at zero time and after feeding on the different feed rations for 30, 60, 90 and 120 days are shown in Table (1) and graphically presented in Figure (3).

At zero time $\left(\mathrm{T}_{0}\right)$, the amount of red color pixels in the digital photographs of koi fish, $C$. carpio, was very low, ranged from 0 to 77 pixels with an average of $16.2 \pm 24.92$ pixels (Table, $1)$.

After 30 days, the highest amount of red color pixels was recorded in $\mathrm{T}_{7}$ (diet contained the 3 mixed food additives), ranged from 26 - 2721 pixels, with an average of $1127.3 \pm 1069.82$ pixels. Followed by $\mathrm{T}_{3}$ (diet contained carrot), ranged from 0- 2381 pixels, with an average of $974.8 \pm 1133.43$ pixels. While the lowest red pixels amount was occurred in $\mathrm{T}_{4}$ (fed on carrot + grape), ranged from 5 - 755 pixels, with an average of 253.2 235.74 pixels; compared with control, ranged from $0-1186$ pixels, with an average of $296.4 \pm 413.05$ pixels (Table 1 and Fig. $3)$.

After 60 days, the red color was slightly improved in all treated groups, except $\mathrm{T}_{3}$, in which the red color pixels amount greatly decreased, recording the lowest value $(541.3 \pm 1472.22$ pixels) after the control group (340.3 \pm 723.14 pixels). Also, the highest red color pixels amount was recorded in $\mathrm{T}_{7}$, in which it ranged from 0 - 8251 pixels, with an average of $1489.1 \pm 2626.94$ pixels. It followed by $\mathrm{T}_{6}$, with an average of $1158.8 \pm 1092.39$ pixels (Table 1 and Figure, 3 ).

After 90 days, the red color pixels amounts were moderately increased in all experimental groups, except $\mathrm{T}_{3}$, in which it was slightly decreased, recording the lowest value $(420.1 \pm 703.61$ pixels), and it followed by the control group (458.0 4402.1 pixels). In the same manner, the highest average of red color pixels amount $(2184.6 \pm 1203.53$ pixels $)$ was recorded in $\mathrm{T}_{7}$. It followed by $\mathrm{T}_{6}$, with an average of $1672.5 \pm 1147.87$ pixels (Table 1 and Fig. 3 ).

After 120 days, the red color pixels amounts reached the maximum values in all experimental groups, except $\mathrm{T}_{3}$, in which it was greatly decreased, recording its minimum value (298.8 \pm 396.41 pixels). The highest average of red color pixels amount was recorded in $\mathrm{T}_{7}$, ranged from 2069 - 3783 pixels, with an average of $2880.2 \pm 528.44$ pixels. Followed by $\mathrm{T}_{4}$ and $\mathrm{T}_{6}$ (diets contained carrot), with averages of 2487.5 \pm 3579.06 and 2186.2 \pm 2121.94 pixels, respectively (Table 1, Fig. 3 and Plates, I\&II).

The results showed that, the amount of red color pixels was significantly increased, with increase of feeding period in $\mathrm{T}_{7}, \mathrm{~T}_{6}$ and $\mathrm{T}_{4}$ (in which carrot was mixed with another additive). 


\section{Ahmad M. Azab et al.}

While, it was significantly decreased with increase of feeding period in $\mathrm{T}_{3}$, in which feed ration contained carrot only (Table 1, Fig. 3 and Plates, I\&II).

Table (1): Amount of red color (pixels) in the pictures of koi fish, $C$. carpio, fed on different food additives, during different periods.

\begin{tabular}{|c|c|c|c|c|c|}
\hline \multicolumn{2}{|c|}{ Treatments } & 30 days & 60 days & 90 days & 120 days \\
\hline \multirow{2}{*}{$\mathbf{T}_{\mathbf{0}}$} & Range & \multicolumn{4}{|c|}{0 - 77} \\
\hline & $\begin{array}{c}\text { Mean } \\
\pm \text { SD }\end{array}$ & \multicolumn{4}{|c|}{$16.2 \pm 24.92$} \\
\hline \multirow{2}{*}{$\mathbf{C}$} & Range & $0-1186$ & $0-2298$ & $52-1288$ & $17-1735$ \\
\hline & $\begin{array}{c}\text { Mean } \\
\pm \text { SD } \\
\end{array}$ & $296.4 \pm 413.05$ & $340.3 \pm 723.14$ & $458.0 \pm 402.10$ & $669.3 \pm 500.04$ \\
\hline \multirow{2}{*}{ T1 } & Range & $0-2124$ & $0-2208$ & $0-2262$ & $0-3478$ \\
\hline & $\begin{array}{l}\text { Mean } \\
\pm \text { SD }\end{array}$ & $452.1 \pm 672.6$ & $785.7 \pm 925.44$ & $942.1 \pm 732.78$ & $1098.5 \pm 1206.99$ \\
\hline \multirow{2}{*}{$\mathbf{T} 2$} & Range & $0-1356$ & $0-3201$ & $0-2700$ & $0-4844$ \\
\hline & $\begin{array}{c}\text { Mean } \\
\pm \text { SD }\end{array}$ & $320.9 \pm 490.89$ & $1096.3 \pm 1393.57$ & $1215.1 \pm 1198.61$ & $1334.0 \pm 1503.11$ \\
\hline \multirow{2}{*}{ T3 } & Range & $0-2381$ & $0-4708$ & $0-2354$ & $0-921$ \\
\hline & $\begin{array}{c}\text { Mean } \\
\pm \text { SD }\end{array}$ & $974.8 \pm 1133.43$ & $541.3 \pm 1472.22$ & $420.1 \pm 703.61$ & $298.8 \pm 396.41$ \\
\hline \multirow{2}{*}{ T4 } & Range & $5-755$ & $0-1341$ & $222-6541$ & 405- 12000 \\
\hline & $\begin{array}{c}\text { Mean } \\
\pm \text { SD }\end{array}$ & $253.2 \pm 235.74$ & $617.1 \pm 533.56$ & $1552.3 \pm 1905.8$ & $2487.5 \pm 3579.0$ \\
\hline \multirow{2}{*}{ T5 } & Range & $0-1106$ & $0-1567$ & $1-1978$ & $0-3009$ \\
\hline & $\begin{array}{c}\text { Mean } \\
\pm \text { SD }\end{array}$ & $308.3 \pm 438.71$ & $460.8 \pm 630.19$ & $496.4 \pm 650.71$ & $532.1 \pm 1144.65$ \\
\hline \multirow{2}{*}{ T6 } & Range & $0-2616$ & $0-2954$ & $737-5078$ & $224-8540$ \\
\hline & $\begin{array}{c}\text { Mean } \\
\pm \text { SD }\end{array}$ & $556.1 \pm 682.83$ & $1158.8 \pm 1092.3$ & $1672.5 \pm 1147.8$ & $2186.2 \pm 2121.9$ \\
\hline \multirow{2}{*}{ T7 } & Range & $26-2721$ & $0-8251$ & $1073-5160$ & $2069-3783$ \\
\hline & $\begin{array}{l}\text { Mean } \\
\pm \text { SD }\end{array}$ & $1127.3 \pm 1069.82$ & $1489.1 \pm 2626.94$ & $2184.6 \pm 1203.53$ & $2880.2 \pm 528.44$ \\
\hline
\end{tabular}


Effect of some food additives on color enhancement of koi fish, Cyprinus carpio (Linnaeus, 1758)

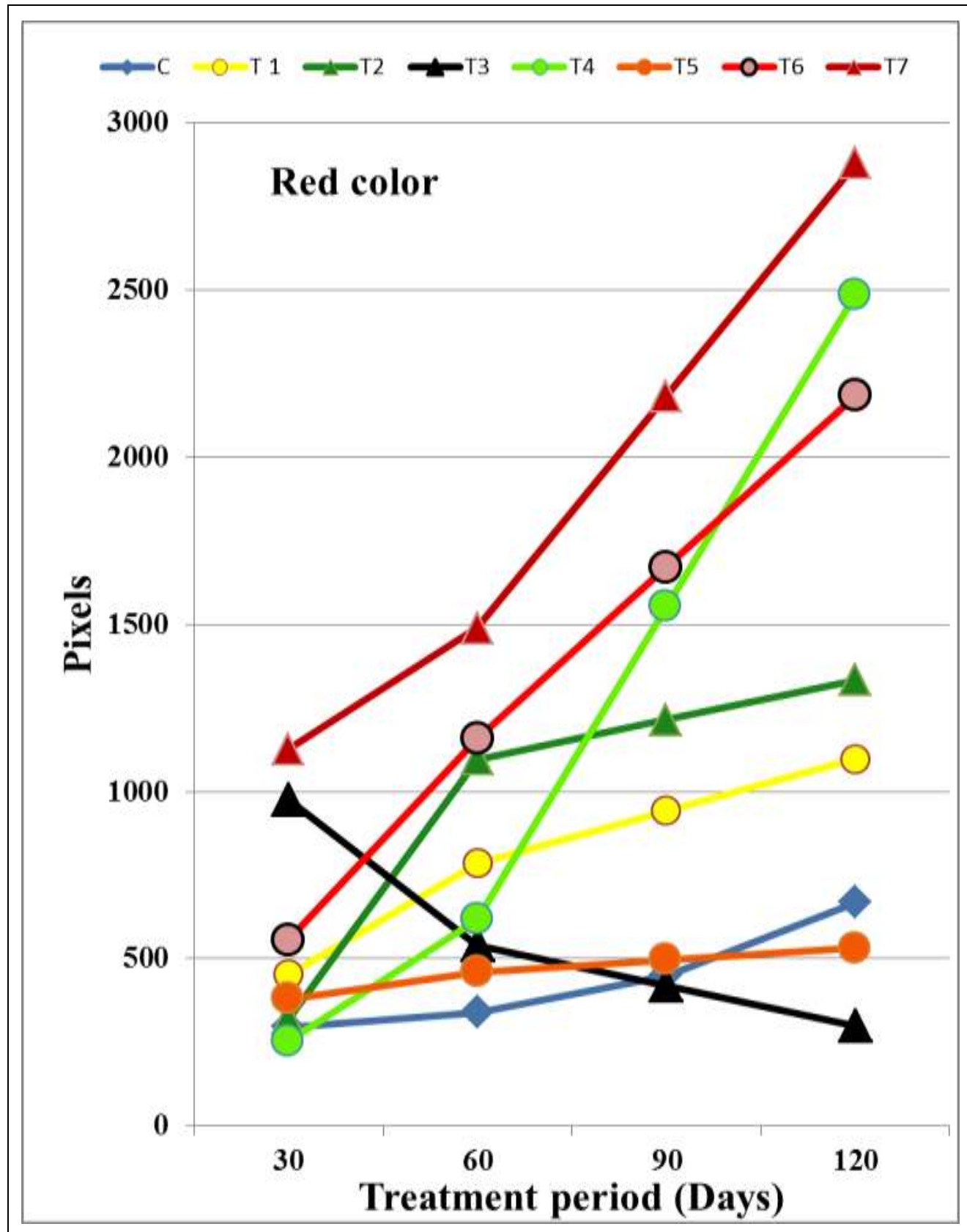

Fig. (3): Relationship between the red color pixels amounts (pixels) and the treatment period (days) in the pictures of koi fish, $C$. carpio, fed on different food additives. 
Ahmad M. Azab et al.

\subsection{Yellow color:}

The amount of yellow color pixels in the digital photographs of koi fish, C. carpio, at zero time and after feeding on the different feed rations for 30, 60, 90 and 120 days are shown in Table (2) and graphically presented in Figure (4).

At zero time $\left(\mathrm{T}_{0}\right)$, the amount of yellow color pixels in the digital photographs of koi fish, C. carpio, was very low, ranged from 0 to 964 pixels with an average of $202.3 \pm 255.79$ pixels (Table 2).

After 30 days, the highest yellow color pixels amount was recorded in $\mathrm{T}_{4}$ (diet contained carrot and grape). It ranged from 108 - 3625 pixels, with an average of $1415.0 \pm 1256.96$ pixels. Followed by $\mathrm{T}_{3}$ (diet contained carrot), ranged from $45-2761$ pixels, with an average of $1076.1 \pm 1239.66$ pixels. While the lowest yellow pixels amount was occurred in $\mathrm{T}_{6}$ (fed on carrot + turnip), ranged from 0 - 98 pixels, with an average of $8.2 \pm 28.29$ pixels; compared with the

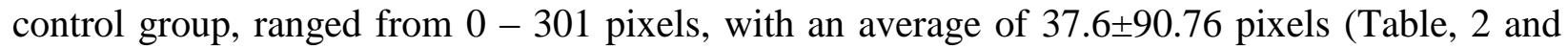
Fig. 4).

After 60 days, the yellow color was greatly improved in all treated groups, except $T_{1}$, (feed contained turnip), in which the yellow color pixels amount greatly decreased, recording the lowest value (63.8 \pm 84.13 pixels) comparing to the control group (448.4 \pm 256.16 pixels). The highest yellow color pixels amount was recorded in $\mathrm{T}_{4}$ (diet contained carrot and grape). It ranged from $63-4547$ pixels, with an average of $2104.3 \pm 1732.95$ pixels. Followed by $\mathrm{T}_{3}$ (diet contained carrot), ranged from $8-2197$ pixels, with an average of $1767.8 \pm 3301.11$ pixels. Then, it followed by $\mathrm{T}_{6}$, with an average of $1561.9 \pm 2322.57$ pixels (Table 2 and Fig. 4 ).

After 90 days, the yellow color pixels amounts were greatly varied in all experimental groups. It was greatly increased in $\mathrm{T}_{3}$ and reached to the highest yellow color pixels amount at 90 days of treatment; ranging from $314-9267$ pixels, with an average of $4875.5 \pm 3755.36$ pixels. It followed by $\mathrm{T}_{6}$, with an average of $2428.4 \pm 1364.6$ pixels. The lowest yellow color pixels amount was recorded in the control group and $\mathrm{T}_{1}$; with averages of $57.4 \pm 91.24$ pixels and 66.1 \pm 95.64 pixels, respectively (Table 2 and Fig. 4).

After 120 days, the yellow color pixels amount was greatly increased and reached the maximum values in $T_{3}$, ranged from $27-18522$ pixels, with an average of $7983.1 \pm 8458.72$ pixels. It followed by $\mathrm{T}_{6}$, which ranged from 0-8577 pixels with an average of 3294.8 \pm 3644.5 pixels. The lowest yellow color pixels amount was recorded in $\mathrm{T}_{7}$, which ranged from 0 - 98 pixels, with an average of $49.5 \pm 28.29$ pixels (Table 2, Fig. 4 and Plates, I\&II).

The results showed that, the yellow color pixels amount was significantly increased with increase of feeding period in $\mathrm{T}_{3}$ and $\mathrm{T}_{6}$ (in which carrot was alone or mixed with turnip). But, it was very low during the whole period of study in $\mathrm{T}_{7}$ (Table 2, Fig. 4 and Plates, I\&II). 
Effect of some food additives on color enhancement of koi fish, Cyprinus carpio (Linnaeus, 1758)

Table (2): Amount of yellow color pixels in the pictures of koi fish, $C$. carpio fed on different food additives, during different periods.

\begin{tabular}{|c|c|c|c|c|c|}
\hline \multicolumn{2}{|c|}{ Treatments } & 30 days & 60 days & 90 days & 120 days \\
\hline \multirow[b]{2}{*}{$\mathbf{T}_{\mathbf{0}}$} & Range & \multicolumn{4}{|c|}{0 - 964} \\
\hline & $\begin{array}{l}\text { Mean } \\
\pm \text { SD } \\
\end{array}$ & \multicolumn{4}{|c|}{$202.3 \pm 255.79$} \\
\hline \multirow{2}{*}{$\mathbf{C}$} & Range & $0-301$ & $14-791$ & $0-295$ & $2-598$ \\
\hline & $\begin{array}{c}\text { Mean } \\
\pm \text { SD }\end{array}$ & $37.6 \pm 90.76$ & $448.4 \pm 256.16$ & $57.4 \pm 91.24$ & $169.0 \pm 215.57$ \\
\hline \multirow{2}{*}{ T1 } & Range & $0-789$ & $0-179$ & $0-316$ & $0-630$ \\
\hline & $\begin{array}{l}\text { Mean } \\
\pm \text { SD }\end{array}$ & $248.3 \pm 211.27$ & $63.8 \pm 84.13$ & $66.1 \pm 95.64$ & $68.4 \pm 197.65$ \\
\hline \multirow{2}{*}{$\mathbf{T} 2$} & Range & $0-283$ & $0-850$ & $0-826$ & $0-1077$ \\
\hline & $\begin{array}{l}\text { Mean } \\
\pm \text { SD }\end{array}$ & $99.9 \pm 103.64$ & $350.6 \pm 370.43$ & $257.5 \pm 268.76$ & $164.3 \pm 379.72$ \\
\hline \multirow[b]{2}{*}{ T3 } & Range & 45- 2761 & $8-2197$ & $314-9267$ & $27-18522$ \\
\hline & $\begin{array}{l}\text { Mean } \\
\pm \text { SD }\end{array}$ & $\begin{array}{c}1076.1 \pm 1239.6 \\
6\end{array}$ & $\begin{aligned} & 1767.8 \\
\pm & 3301.11\end{aligned}$ & $\begin{array}{c}4875.5 \pm 3755.3 \\
6\end{array}$ & $\begin{array}{c}7983.1 \pm 8458.7 \\
2\end{array}$ \\
\hline \multirow{2}{*}{ T4 } & Range & $108-3625$ & $63-4547$ & $83-3823$ & $8-7524$ \\
\hline & $\begin{array}{l}\text { Mean } \\
\pm \text { SD }\end{array}$ & $\begin{array}{c}1415.0 \pm 1256.9 \\
6\end{array}$ & $2104.3 \pm 1732.95$ & $\begin{array}{c}1566.2 \pm 1134.0 \\
9\end{array}$ & $\begin{array}{c}1028.1 \pm 2096.2 \\
8\end{array}$ \\
\hline \multirow[b]{2}{*}{ T5 } & Range & $0-5039$ & $0-9739$ & $3-4873$ & $5-2639$ \\
\hline & $\begin{array}{l}\text { Mean } \\
\pm \text { SD }\end{array}$ & $827.4 \pm 1802.44$ & $1103.5 \pm 2780.69$ & $\begin{array}{c}1112.2 \pm 1338.0 \\
1\end{array}$ & $\begin{array}{c}1120.9 \pm 1039.2 \\
7\end{array}$ \\
\hline \multirow{2}{*}{ T6 } & Range & $0-98$ & $0-5319$ & $2-4289$ & $0-8577$ \\
\hline & $\begin{array}{l}\text { Mean } \\
\pm \text { SD }\end{array}$ & $8.2 \pm 28.29$ & $1561.9 \pm 2322.57$ & $2428.4 \pm 1364.6$ & $3294.8 \pm 3644.5$ \\
\hline \multirow{2}{*}{ T7 } & Range & $17-574$ & $0-2915$ & $0-1469$ & $0-98$ \\
\hline & $\begin{array}{c}\text { Mean } \\
\pm \text { SD }\end{array}$ & $243.4 \pm 171.17$ & $412.8 \pm 859.94$ & $231.1 \pm 427.41$ & $49.5 \pm 28.29$ \\
\hline
\end{tabular}


Ahmad M. Azab et al.

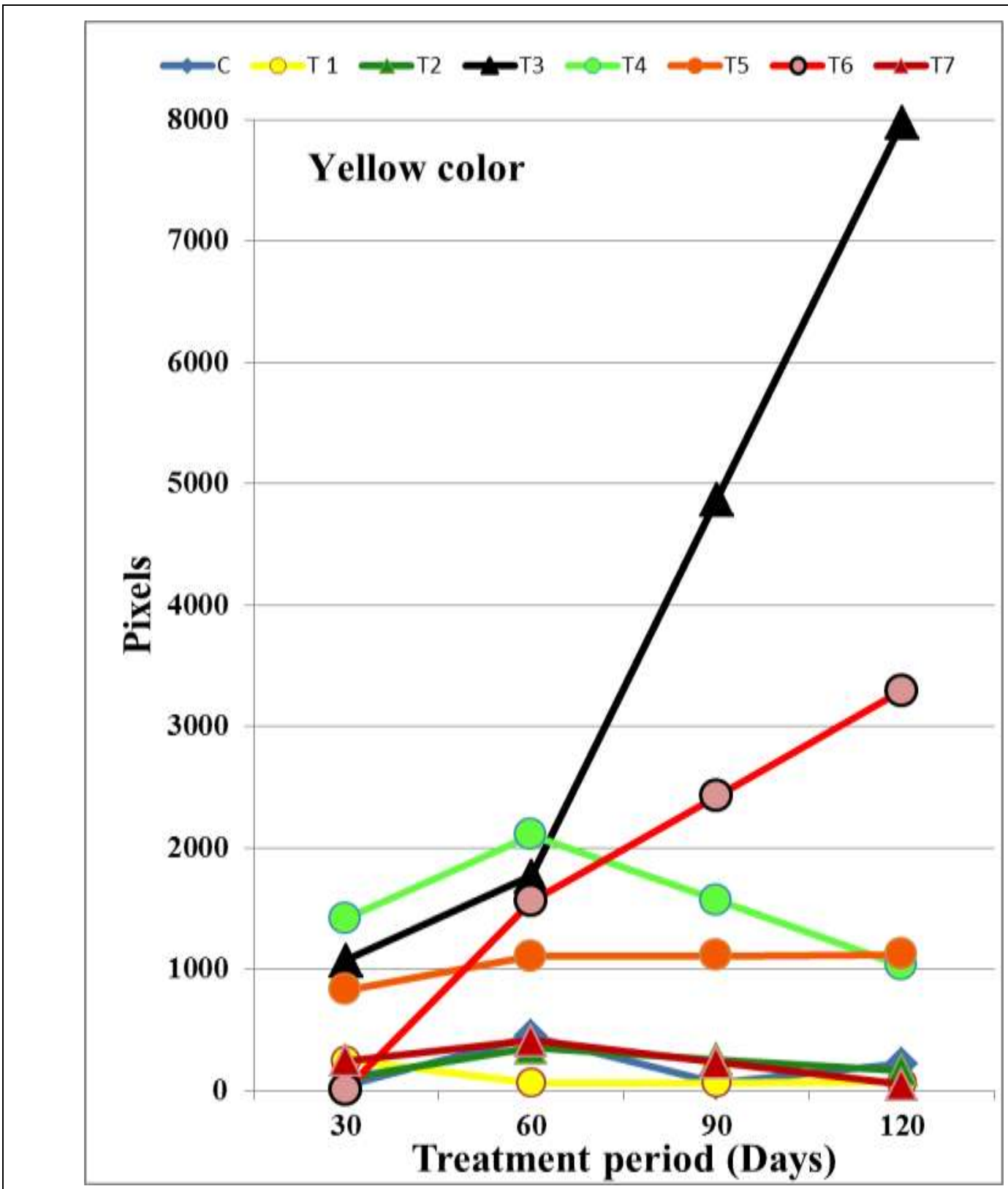

Fig. (4): Relationship between the yellow color pixels amounts (pixels) and the treatment period (days) in the pictures of koi fish, $C$. carpio, fed on different food additives.

\subsection{Total color:}

The amount of total (red and yellow) color pixels in the digital photographs of koi fish, $C$. carpio, after feeding on the different feed rations for 30, 60, 90 and 120 days are shown in Table (3) and graphically presented in Figure (5).

At zero time $\left(\mathrm{T}_{0}\right)$, the amount of total color pixels in the digital photographs of koi fish, Cyprinus carpio, was very low, ranged from 0 to 979 pixels with an average of $218.5 \pm 250.55$ pixels (Table 3). 


\section{Effect of some food additives on color enhancement of koi fish, Cyprinus carpio (Linnaeus, 1758)}

After 30 days, the highest total color pixels amount was recorded in $\mathrm{T}_{3}$ (diet contained carrot), it ranged from 155 - 2761 pixels, with an average of $2050.9 \pm 865.23$ pixels. Followed by $\mathrm{T}_{4}$ (diet contained carrot and grape), it ranged from 390 - 3630 pixels, with an average of $1668.2 \pm 1157.76$ pixels. While the lowest total color pixels amount was occurred in control group, it ranged from 4 - 1194 pixels, with an average of 333.9 411.06 pixels (Table 3 and Fig. $5)$.

After 60 days, the total color was slightly improved in all treated groups. The highest total color pixels amount was recorded in $\mathrm{T}_{4}$, in which it ranged from $122-4547$ pixels, with an average of $2721.4 \pm 1481.33$ pixels. Also, $\mathrm{T}_{6}$ recorded the highest value of total color pixels, ranged from $1004-5325$ pixels, with an average of $2720.7 \pm 1626.24$ pixels. While the lowest total color pixels amount was recorded in the control group and T1, with averages of 788.6 \pm 546.16 and 849.5 \pm 867.31 pixels, respectively (Table 3 and Fig. 5).

After 90 days, the total color pixels amounts were greatly increased in all experimental groups, except the control group, in which it was slightly decreased, recording the lowest value (506.1 \pm 420.7 pixels). It also followed by $\mathrm{T}_{1}$ with an average of $1008.2 \pm 708.88$ pixels. The highest total color pixels amount was recorded in $\mathrm{T}_{3}$, ranged from $710-11202$ pixels, with an average of $5259.5 \pm 3951.91$ pixels. It followed by $\mathrm{T}_{6}$, it ranged from $1574-9366$ pixels, with an average of $4100 \pm 2112.5$ pixels (Table 3 and Fig. 5).

After 120 days, the total color pixels amounts reached the maximum values in all experimental groups. The lowest average of total color pixels (1166.9 \pm 1198.27 pixels) was recorded in $\mathrm{T} 1$ (diet contained turnip). The highest average of total color pixels amount was

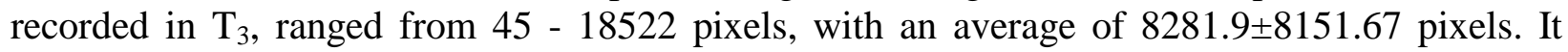
followed by $\mathrm{T}_{6}$, ranged from $236-17117$ pixels, with averages of $5481 \pm 5137.92$ pixels (Table 3 , Fig. 5 and Plates I\&II).

These results showed that, the total color pixels amount was significantly increased, with increase of feeding period, in $\mathrm{T}_{3}, \mathrm{~T}_{6}$ and $\mathrm{T}_{4}$ (in which carrot was mixed with another additive). While, it was slightly decreased with increase of feeding period in $T_{7}$ and $T_{5}$, in which feed ration contained grape and turnip (Table 3, Fig. 5 and Plates I\&II). 
Ahmad M. Azab et al.

Table (3): Amount of total color pixels in the pictures of koi fish, C. carpio fed on different food additives, during different periods.

\begin{tabular}{|c|c|c|c|c|c|}
\hline \multicolumn{2}{|c|}{ Treatments } & 30 days & 60 days & 90 days & 120 days \\
\hline \multirow{2}{*}{ T0 } & Range & \multicolumn{4}{|c|}{0 - 979} \\
\hline & $\begin{array}{c}\text { Mean } \\
\pm \text { SD } \\
\end{array}$ & \multicolumn{4}{|c|}{$218.5 \pm 250.55$} \\
\hline \multirow{2}{*}{$\mathbf{C}$} & Range & $4-1194$ & $367-2312$ & $52-1194$ & $543-2797$ \\
\hline & $\begin{array}{c}\text { Mean } \\
\pm \text { SD }\end{array}$ & $333.9 \pm 411.06$ & $788.6 \pm 546.16$ & $506.1 \pm 420.70$ & $1540.4 \pm 887.26$ \\
\hline \multirow[b]{2}{*}{ T1 } & Range & $11-2274$ & $114-2208$ & $57-2274$ & $0-3478$ \\
\hline & $\begin{array}{l}\text { Mean } \\
\pm \text { SD }\end{array}$ & $700.4 \pm 665.64$ & $849.5 \pm 867.31$ & $1008.2 \pm 708.88$ & $\begin{array}{c}1166.9 \pm 1198.2 \\
7\end{array}$ \\
\hline \multirow[b]{2}{*}{$\mathbf{T} 2$} & Range & $34-1356$ & $254-3201$ & $226-2813$ & $0-4844$ \\
\hline & $\begin{array}{l}\text { Mean } \\
\pm \text { SD }\end{array}$ & $420.8 \pm 427.19$ & $\begin{array}{c}1446.8 \\
\pm 1142.43\end{array}$ & $\begin{array}{c}1472.6 \pm 1054.0 \\
7\end{array}$ & $\begin{array}{c}1498.3 \pm 1474.3 \\
5\end{array}$ \\
\hline \multirow{2}{*}{ T3 } & Range & $155-2761$ & $11-10928$ & $710-11202$ & $45-18522$ \\
\hline & $\begin{array}{l}\text { Mean } \\
\pm \text { SD }\end{array}$ & $2050.9 \pm 865.23$ & $2309.1 \pm 3498.05$ & $\begin{array}{c}5295.5 \pm 3951.9 \\
1\end{array}$ & $\begin{array}{c}8281.9 \pm 8151.6 \\
7\end{array}$ \\
\hline \multirow[b]{2}{*}{ T4 } & Range & $390-3630$ & $122-4547$ & $1016-6626$ & $471-12026$ \\
\hline & $\begin{array}{l}\text { Mean } \\
\pm \text { SD }\end{array}$ & $\begin{array}{c}1668.2 \pm 1157.7 \\
6\end{array}$ & $2721.4 \pm 1481.33$ & $\begin{array}{c}3118.5 \pm 1555.0 \\
8\end{array}$ & $\begin{array}{c}3515.6 \pm 3838.8 \\
1\end{array}$ \\
\hline \multirow[b]{2}{*}{ T5 } & Range & $0-5039$ & $0-10685$ & $62-6850$ & $124-3015$ \\
\hline & $\begin{array}{l}\text { Mean } \\
\pm \text { SD }\end{array}$ & $\begin{array}{c}1207.7 \pm 1663.2 \\
8\end{array}$ & $1564.3 \pm 2953.95$ & $1608.6 \pm 1790.7$ & $\begin{array}{c}1653.0 \pm 1054.9 \\
2\end{array}$ \\
\hline \multirow{2}{*}{ T6 } & Range & $56-2616$ & $1004-5325$ & $1574-9366$ & $236-17117$ \\
\hline & $\begin{array}{c}\text { Mean } \\
\pm \text { SD }\end{array}$ & $564.3 \pm 676.13$ & $2720.7 \pm 1626.24$ & $4100 \pm 2112.5$ & $5481 \pm 5137.92$ \\
\hline \multirow{2}{*}{ T7 } & Range & $266-2818$ & $73-11166$ & $1073-6629$ & $2072-881$ \\
\hline & $\begin{array}{l}\text { Mean } \\
\pm \text { SD }\end{array}$ & $1370.6 \pm 941.99$ & $1901.9 \pm 3355.63$ & $\begin{array}{c}2415.8 \pm 1561.9 \\
3\end{array}$ & $2929.6 \pm 550.4$ \\
\hline
\end{tabular}


Effect of some food additives on color enhancement of koi fish, Cyprinus carpio (Linnaeus, 1758)

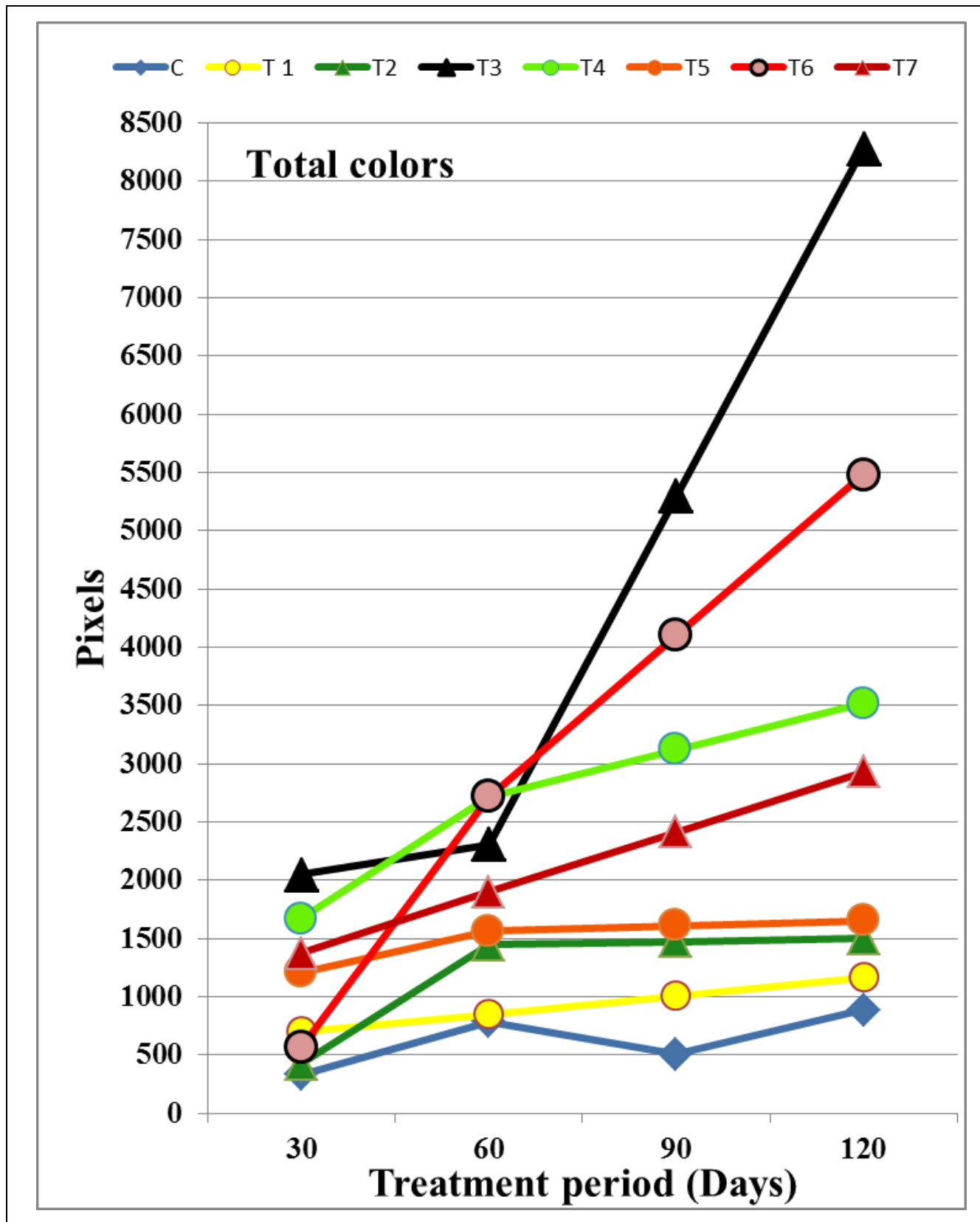

Fig. (5): Relationship between the total color pixels amounts (pixels) and the treatment period (days) in the pictures of koi fish, $C$. carpio, fed on different food additives. 
Ahmad M. Azab et al.

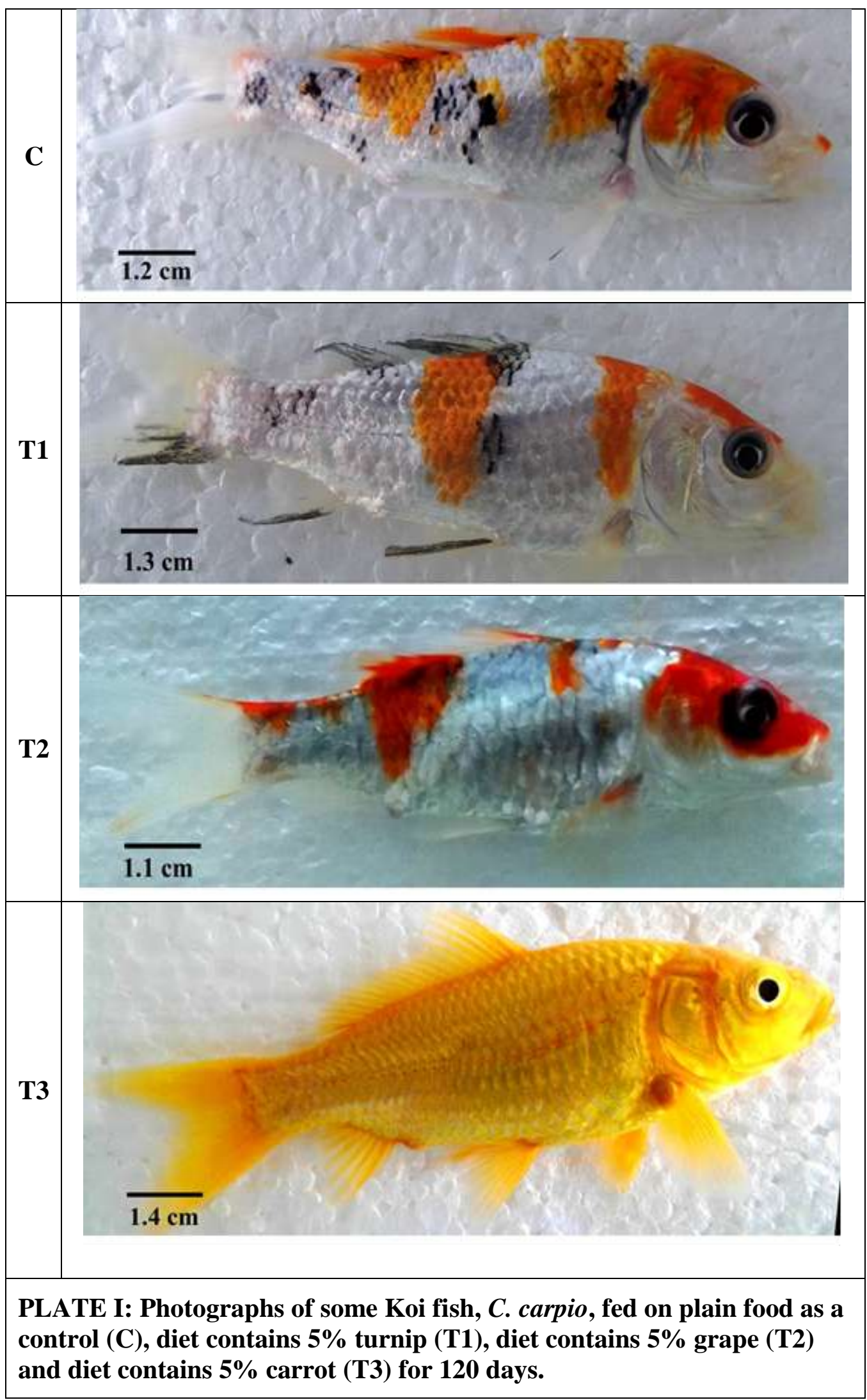


Effect of some food additives on color enhancement of koi fish, Cyprinus carpio (Linnaeus, 1758)

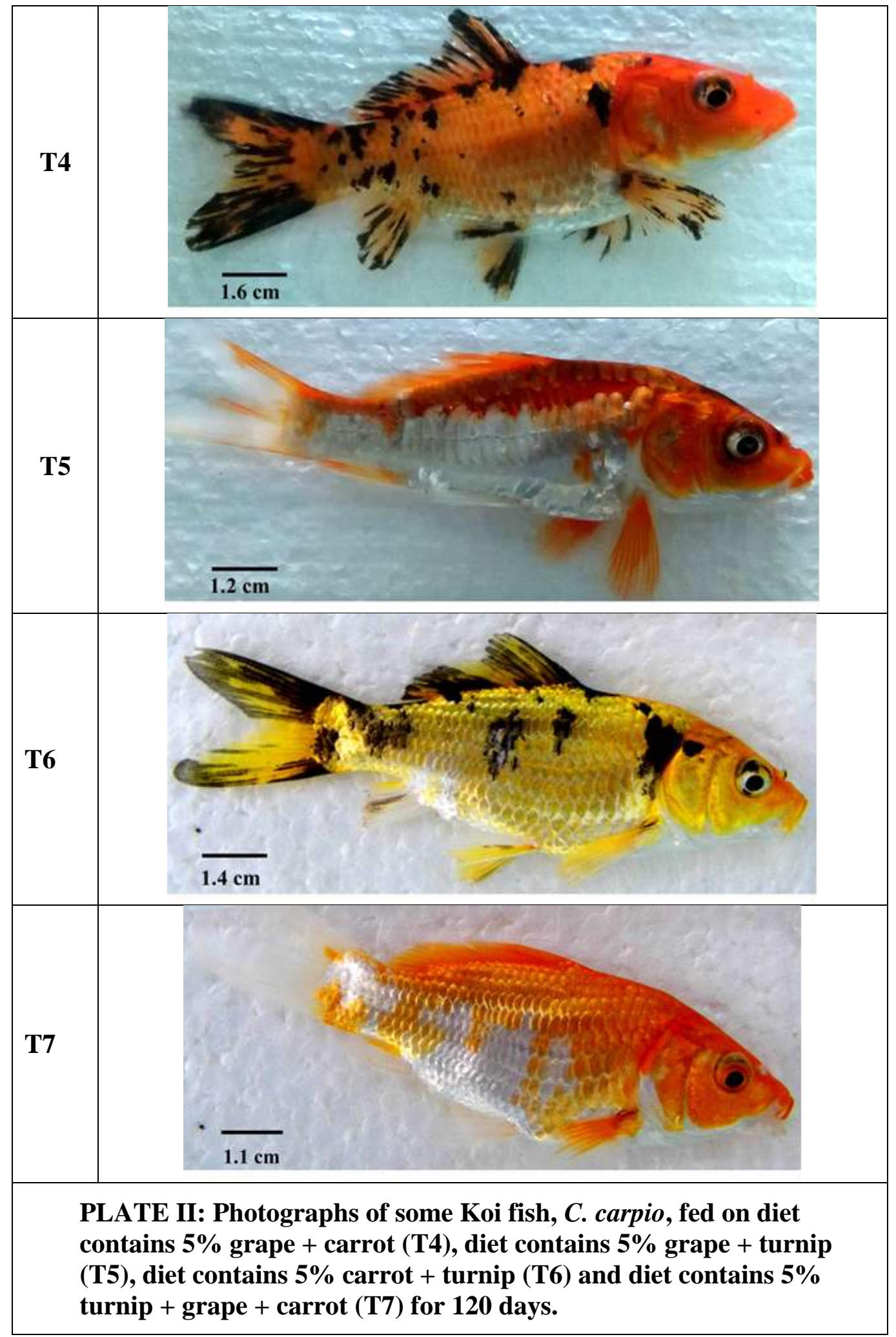


Ahmad M. Azab et al.

\section{DISCUSSION}

Ornamental fish are characterized by a wide diversity of colours, colour patterns and success in the ornamental fish trade is very much dependent on the bouncy colour of the fish. Color is one of the major factors, which determines the price of aquarium fish in the world market [5].

Color enhancing diets may contain additional natural pigments to enhance colors of ornamental fish. People involved in the trade of ornamental fish are constantly exploring methods of enhancing skin coloration. A direct relationship between dietary carotenoid and pigmentation exists in fishes. Unlike other animals, fish lack the ability to synthesis carotenoids and entirely depend on their dietary sources. If enhancement of colouration can be done by administering pigment enriched feed, it will definitely improve the quality and cost of the fish ${ }^{[14]}$

In the present study, the highest amount of the red color pixels was recorded in $\mathrm{T}_{7}$ ( 3 mixed food additives: carrot + turnip + grape) at 30, 60, 90 and 120 days; in T6 (carrot + turnip) at 60,90 and 120 days; and in $\mathrm{T}_{4}$ (carrot + grape) at 30,90 and 120 days. It may be due to the source of red colour, which found in different additives of carotenoids (carrot, turnip and grape). But, the lowest amount of the red color pixels occurred in $T_{5}$ (grape + turnip) at 60,90 and 120 days; in T3 (carrot) at 60, 90 and 120 days and as well as the control group at the whole period of experiment.

In the present study, the average in the amount of red color pixels reached its maximum value (2880.2 \pm 528.44$)$ in $\mathrm{T}_{7}$ (turnip + grape + carrot) at the end of experiment (120 days). The enhancement of the amount red color pixels may be due to the combination between the carotenoids in the three experimental additives.

Generally, the present study showed that, the amount of red color pixels was significantly increased, with increase of feeding period in $\mathrm{T}_{7}, \mathrm{~T}_{6}$ and $\mathrm{T}_{4}$ (in which carrot was mixed with another additive). While, it was significantly decreased with the increase of feeding period in $\mathrm{T}_{3}$, in which feed ration contained carrot only. Many reports have demonstrated that, skin color change over time depended on the level of carotenoid in the diet and differed among species $^{[6,15-17] \text {. }}$.

Carotenoids form the most important classes of plant pigments and play a crucial role in defining the quality parameters of fruit and vegetables. Carotenoids are of great interest due to their essential biological functions in both plants and animals ${ }^{[18]}$. Carotenoids are the primary source of pigmentation in ornamental tropical fish, responsible for various colours like yellow, red and other related colours. Normally these are obtained through substances rich in carotenoid content in the food chain of the aquatic organisms. But commercial feed ingredients such as yellow corn, corn gluten meal and alfa alfa are used as sources of carotenoids such as zeaxanthin and lutein ${ }^{[19-20]}$.

Some authors used another sources of carotenoids for enhansment of color. [21] used Haematococcus pluvialis as a safe natural source of astaxanthin derived from micro algae which resulted in extensive pigmentation in koi and tropical fishes. [22] observed a positive effect of dietary carotenoid on the growth of red tilapia. [23] reported that, the enhancement of colour in male gourami when fed with carotenoid pigment source. [24] reported that, Spirulina induced the growth and body colour of crucian carp and [20] mentioned that, Rosa rubiginosa petals enhanced the coloration of soardtail fish, Xiphophorus helleri.

In the present study, the highest amount of yellow color pixels was recorded in $\mathrm{T}_{4}$ (grape+carrot) at 30 and 60 days only. But, this amount of yellow color pixels started to increase

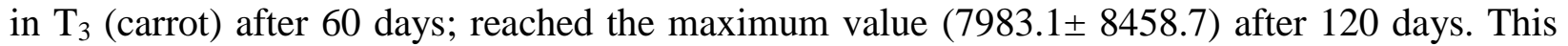




\section{Effect of some food additives on color enhancement of koi fish, Cyprinus carpio (Linnaeus, 1758)}

means that, the sources of red color in carotinoids of carrot, which gave high amount of red color pixels after 30 days only, they shared sources of yellow color in carotinoids of carrot giving more yellow color pixels after a long period.

These findings were in agreement with some other studies ${ }^{[25-27]}$. It was found that, carrot (Daucus arota) is a good source of $\beta$ carotene $\left(10800 \mu \mathrm{g} \mathrm{g}^{-1}\right.$ wet weight) and $\alpha$ carotene $(3610 \mu \mathrm{g}$ $\mathrm{g}^{-1}$ wet weight) which is higher than many fruits, uncooked vegetables and seeds. In addition due to its low price and easy access, carrot is a good source of food additive in fish culture.

The enhancement of the yellow color pixels may be due to carotenoids in carrot; where, carotenoid pigments play a decisive role in intermediary metabolism and that could also enhance nutrient utilization and various sources of carotenoid pigments were tried for enhancing pigmentation $^{[28-29]}$.

The lowest amounts of yellow color pixels occurred in $\mathrm{T}_{6}$ (carrot + turnip) after 30 days and in $\mathrm{T}_{1}$ (turnip) and in $\mathrm{T}_{7}$ (grape+ carrot+ turnip), after 60, 90 and 120 days. This means that, the sources of yellow color in carotinoids of turnip were very low.

In the present study, the total amount of color pixels over the rearing period of 120 days exhibited greater in all treatments compared with the control. It may be due to the carotenoids in turnip, grape and carrot.

Although some authors claim that, the biological functions of carotenoids in fish are still speculative ${ }^{[30]}$, other consider these compounds as important micronutrients that fish are not able to synthesize, therefore, must be included in the diet ${ }^{[31]}$.

In the present study, the highest amounts of total color pixels were recorded in $\mathrm{T}_{3}$ (carrot) after 30, 60, 90 and 120 days. But, the lowest amounts of total color pixels occurred in $\mathrm{T}_{2}$ (grape) at 30 days and in control group and in $\mathrm{T}_{1}$ (turnip) during the whole period of the experiment. This means that, the sources of total colour in carotinoids of carrot were more than grape and turnip and the total colour in carotinoids of turnip and grape were very small.

\section{REFERENCES}

1. FAO (Food and Agricultural Organisation) (2000). World status of ornamental fish, Pp: 225.

2. Kuroki, T. (1981): The latest manual to nishikigoi.Shin-Nippon Kyoiku-Tosho Co. Ltd. Japan, Pp: 272.

3. Kailola, P.J; Williams, M.J.; Stewart, P.C.; Reichelt, R.E.; McNee, A. and Grieve, C. (1993). Australian fisheries resources. Bureau of Resource Sciences, Canberra, Australia, Pp: 422.

4. Goodwin, T.W. (1984). The Biochemistry of the Carotenoids. Volume II Animals. Chapman and Hall, New York, U.S.A., Pp: 224.

5. Saxena, A. (1994). Health; coloration of fish. International Symposium on Aquatic Animal Health: Program and Abstracts. Univ. of California, School of Veterinary Medicine, Davis, CA, U.S.A., Pp: 94.

6. Chatzifotis, S.; Pavlidis, M.; Jimeno, C.D.; Vardanis, G.; Sterioti, A. and Divanach, P. (2005). The effect of different carotenoid sources on skin coloration of cultured red porgy (Pagrus pagrus). Aquacult Res; 36 (15):1517-1525.

7. Hata, M. and Hata, M. (1973). Studies on astaxanthin formation in some freshwater fishes. Tohoku. J. of Agricultural Research, 24(4): 192-196. 
Ahmad M. Azab et al.

8. Halten, B.; Arnmesan, A.; Jobling, M. and Bjerkeng, B. (1997). Carotenoid pigmentation in relation to feed intake, growth and social integration in Arctic char, Salvelinus aipinus (L.), from two anadromous strains, Aquaculture. Nutr., 3: 189-199.

9. Lovell, R.T. (2000). Nutrition of Ornamental Fish. In: Kirk's Current Veterinary Therapy XIII-Small Animal Practice. Bonagura J. (Ed.), Saunders, W.B., Philadelphia, USA; p. 1191-1196.

10. Kowsalya, S.; Chandrasekhar, U. and Balasasirekha, R. (2001). Beta carotene retention in selected green leafy vegetables subjected to dehydration. Ind. J. Nutr. dietet., 38: 374383.

11. Sales, J. and Janssens, G.P.J. (2003). Nutrient requirements of ornamental fish. Aquat Living Resour, 16(6): 533-540.

12. Sinha, A. and Asimi, O.A. (2007). China rose (Hibiscus rosasinensis) petals: a potent natural carotenoid source for goldfish (Carassius auratus L). Aquaculture Res., 38: 1123-1128.

13. Ahilan, B.; Jegan, K.; Felix, N. and Ravaneswaran, K. (2008). Influence of botanical additives on the growth and coloration of adult, Carassius aurates (Linnaeus), Tamil Nadu J. Veterinary \& Animal Sciences, 4 (4): 129-134.

14. Golandaj, A.; Shyama, S.; Dinesh, K.; Sreenath V.R. and Swain, S. (2015). Colour enhancement potential of selected local flowers in Sword tail, Xiphophorus helleri through dietary incorporation. Research Journal of Recent Sciences, 4 (ISC): 37- 43.

15. Dharmaraj S. and Dhevendaran K. (2011). Application of microbial carotenoids as a source of colouration and growth of ornamental fish, Xiphophorus helleri. World Journal of Fish and Marine Sciences, 3(2):137-144.

16. Ho, A.L.F.C.; Zong, S. and Lin, J. (2014). Skin color retention after dietary carotenoid deprivation and dominance mediated skin coloration in clown anemonefish, Amphiprion ocellaris. AACL Bioflux, 7(2):103-115.

17. Yedier, S.; Gümüs, E.; Livengood, E.J. and Chapman F.A. (2014). The relationship between carotenoid type and skin color in the ornamental red zebra cichlid, Maylandia estherae. AACL Bioflux, 7(3):207-216.

18. Eldahshan, O.A. and Singab, A.B. (2013). Carotenoids. Journal of Pharmacognosy and Phytochemistry, 2 (1): 225 - 234.

19. Lovell, R.T. (1992). Dietary enhancement of colour in ornamental fish. Aquaculture Magazine, 18: 77-79.

20. Arulvasu, C.; Ramya, S.; Meena, I.; Chandhirasekar, D. and Sivaganam, S. (2013). Evaluation of natural sources of carotenoid pigments from Rosa rubiginosa on growth, survival and coloration of Xiphophorus helleri fish fry. European Journal of Biological Sciences, 5 (2): 44-49.

21. Ronneberg, H.; Borch, G.; Fox, D. and Jensen, S.L. (1979). Animal carotenoid 19, Natu. Rose. (Technical bulletin 054 Revision Date: 3/27/98).

22. Boonyaratpalin, M. and Unprasert, N. (1989). Effects of pigments from different sources on color changes and growth of red Oreochromis niloticus. Aquaculture, 79: 375-380.

23. Fay, M.F.; Lledó, M.D.; Kornblum, M.M. and Crespo, M.B. (1999). From the waters of Babylon? Populus euphratica in Spain is clonal and probably introduced. Biodiversity and Conservation, 8: 769-778.

24. Peimin, H.; Yinjiong, Z. and Wenhui, H. (1999). Effect of the spirulina feed on the growth and body colour of crucian carp. J. Fish. China/Shuichan Xuebao., 23: 162-168. 


\section{Effect of some food additives on color enhancement of koi fish, Cyprinus carpio (Linnaeus, 1758)}

25. Sommer, T.R.; Potts, W.T. and Morrissy, N.M. (1991). Utilization of microalgal astaxanthin by rainbow trout (Oncorhynchus mykiss). Aquaculture, 94: 79-88.

26. Scott, K.J. and Hart, D.J. (1994). The carotenoid composition of vegetables and fruit commonly consumed in the UK. IFR Publishing Limited, Norwich, England.

27. Pirnia O. and Shadi A. (2015). Color enhancement of zebra Malawi cichlid (Pseudotropheus zebra) using carrot (Daucus carota) as Feed Additive. Journal of Fisheries and Aquatic Science 10 (2): 128-131.

28. Amar, E.C.; Kiron, V.; Satoh, S. and Watanabe, T. (2001). Influence of various dietary synthetic carotenoids on bio-defense mechanisms in rainbow trout, Oncorhynchus mykiss (Walbaum). Aquac. Res., 32 (1): 162-163.

29. Kalinowski, C.T.; Robaina, L.E.; Palacios, H.F.; Schuchardt, D. and Izquierdo, M.S. (2005). Effect of different carotenoid sources and their dietary levels on red porgy (Pagrus pagrus) growth and skin colour. Aquaculture, 244: 223-231.

30. Choubert, G.; Cravedi, J.P. and Laurentie, M. (2005). Pharmocokinetics and bioavailabilities of 14C-ketocarotenoids, astaxanthin and canthaxanthin in rainbow trout, Oncorhynchus mykiss. Aquaculture Research, 15: 1526-1534.

31. Baker, R.T.M.; Pfeiffer, A.M; Schöner, F.J. and Smith-Lemmon, L. (2002). Pigmentation efficacy of astaxanthin and canthaxanthin in fresh-water reared Atlantic salmon, Salmo salar. Animal Feed Science and Technology, 99: 97-106. 
Ahmad M. Azab et al.

تأثير بعض الإضافات الغذائية على تحسين اللون فى أسماك الكوى (سيبرينس كاربيو)

أحمد مسعد عزب، حسن مشحوت محمد خلف الله، هانى ماهر

شعبة علوم البحار و الأسماك ـ قسم علم الحيوانـ كلية العلوم (بنين) - جامعة الأزهر ـ القاهرة

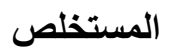

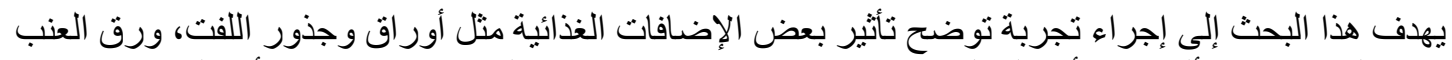

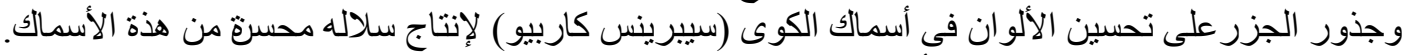

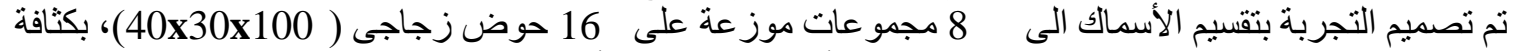

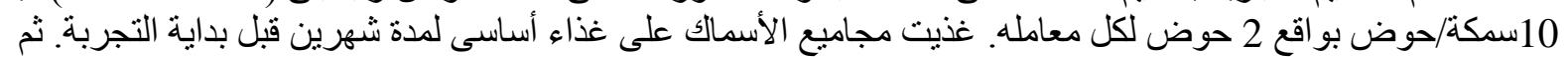

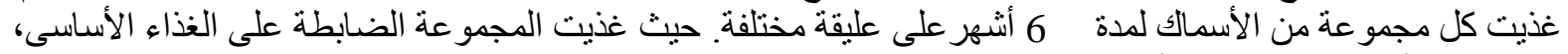

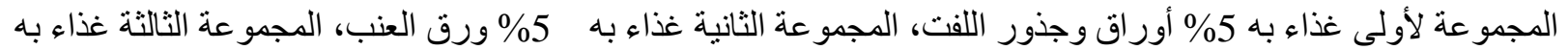

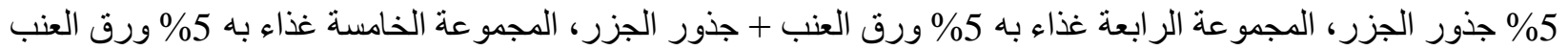

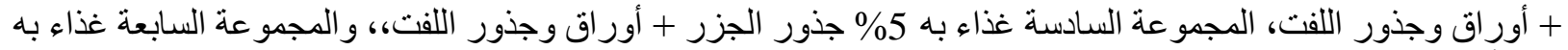

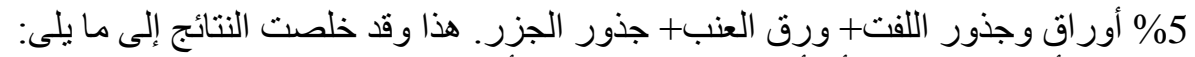

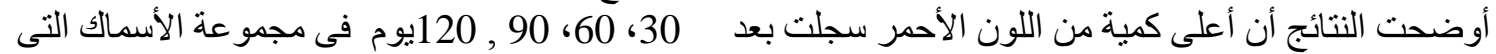

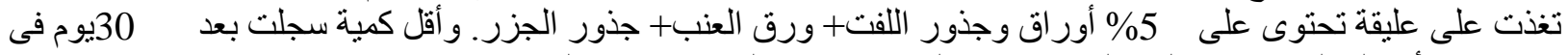

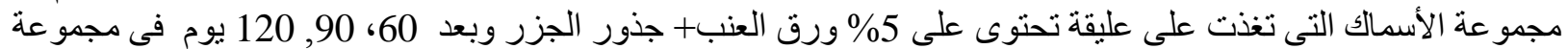

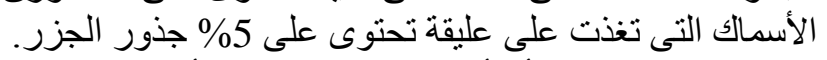

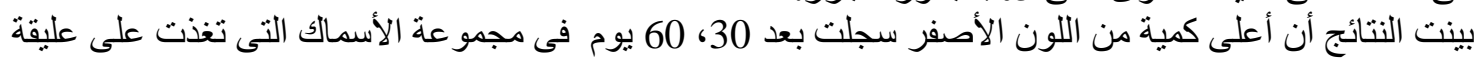

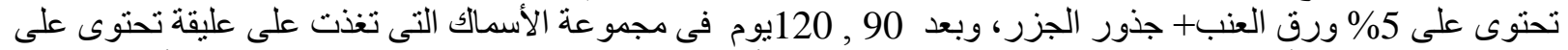

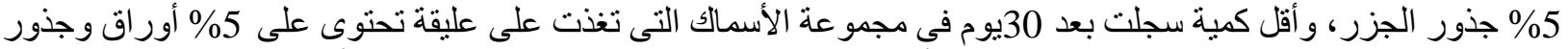

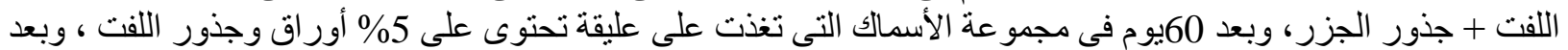

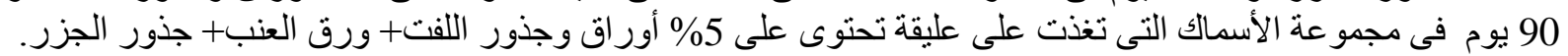

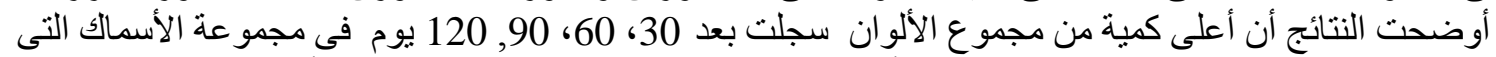

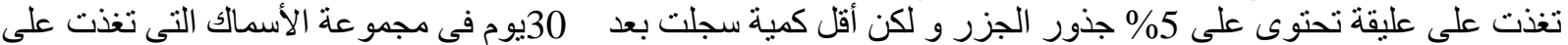

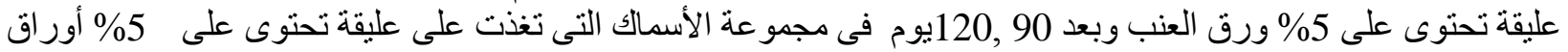

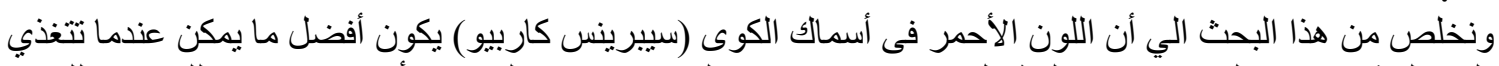
وجذور اللفت.

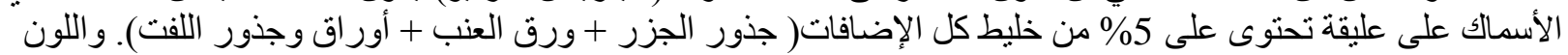

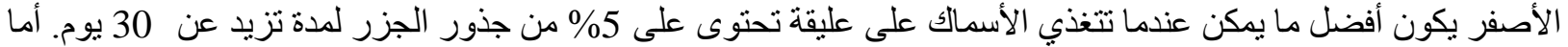

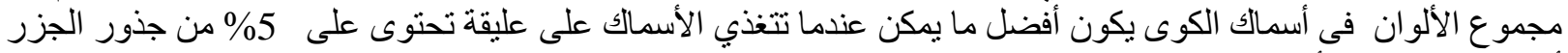
أو جذور الجزر + أوراق وجذور اللفت الكون. 